\title{
Dynamics of forage accumulation in Elephant grass subjected to rotational grazing intensities ${ }^{1}$
}

\author{
Braulio Maia de Lana Sousa ${ }^{2}$, Domicio do Nascimento Júnior ${ }^{3}$, Hélida Christhine de Freitas \\ Monteiro $^{4}$, Sila Carneiro da Silva ${ }^{5}$, Hélio Henrique Vilela ${ }^{3}$, Márcia Cristina Teixeira da Silveira ${ }^{6}$, \\ Carlindo Santos Rodrigues ${ }^{7}$, André Fischer Sbrissia ${ }^{8}$
}

\author{
${ }^{1}$ Financed by FAPEMIG. Support: CNPq, Brazil. \\ 2 Departamento de Zootecnia - UFS, Campus de São Cristóvão, São Cristóvão, SE, Brazil. \\ ${ }^{3}$ Departamento de Zootecnia - UFV, Viçosa, MG, Brazil. \\ ${ }^{4}$ Departamento de Ciências Agrárias - UNIMONTES, Janaúba, SP, Brazil. \\ ${ }^{5}$ Departamento de Zootecnia - USP/ESALQ, Piracicaba, SP, Brazil. \\ ${ }^{6}$ EMBRAPA Pecuária Sul - CPPSUL, Bagé, RS, Brazil. \\ ${ }^{7}$ Instituto Federal de Educação, Ciências e Tecnologia Baiano - IF BAIANO, Núcleo de Ciências Agrárias, Uruçuca, BA, Brazil. \\ ${ }^{8}$ Departamento de Produção Animal e Alimentos - UDESC, Lages, SC, Brazil.
}

\begin{abstract}
We assessed the accumulation dynamics of forage and its components in Elephant grass cv. Napier (Pennisetum purpureum Schum.) that were subjected to three post-grazing height treatments $(30,50$, and $70 \mathrm{~cm})$ from February through May 2009 (experiment one) and December 2009 through May 2010 (experiment two). In experiment one, the grazing events started when the light interception by the canopy reached $95 \%$. The same was adopted for experiment two, except for the first grazing event, which was based on the height of the apical meristems of basal tillers. The experimental design for both experiments was a randomized complete block with three replications. The pastures that were managed at a post-grazing height of $30 \mathrm{~cm}$ exhibited lower rates of leaf and stem growth, total growth and forage accumulation than those that were managed at 50 or $70 \mathrm{~cm}$, indicating that post-grazing height affects Elephant grass. The pastures that were managed at $50 \mathrm{~cm}$ exhibited relatively stable accumulation rates and less stem accumulation. Pastures managed at $70 \mathrm{~cm}$ of pos-grazing height presented more leaf and stem accumulation. Most apical meristems of Elephant grass should be removed in the first grazing when they reach the post-grazing target height of $50 \mathrm{~cm}$. The elevation in the residual post-grazing height, especially in the summer, raises the regrowth vigor in the Elephant grass cv. Napier pasture. The post-grazing height of $30 \mathrm{~cm}$ reduces the growth of the Elephant grass cv. Napier.
\end{abstract}

Key Words: grazing management, growth, light interception, Pennisetum purpureum, senescence, tiller categories

\section{Introduction}

Forage accumulation in pastures is a function of the balance between the growth and senescence processes (Bircham \& Hodgson, 1983) that occur in tillers associated with tillering patterns (e.g., appearance, mortality and survival). Thus, the forage accumulation rate reflects the interactions between the genetic attributes of the plant, the environmental effects on its morphophysiological processes and the grazing management (Lemaire \& Chapman, 1996).

Recent studies with tropical grasses revealed a fairly consistent pattern of forage accumulation in which grass reduces leaf accumulation and enhances stem elongation and leaf senescence rates after the canopy reaches $95 \%$ of light interception (Carnevalli et al., 2006; Da Silva et al., 2009). Thus, the timing of regrowth interruption seems to be well defined. However, the defoliation intensity still needs to be determined. Using severe post-grazing heights can reduce photosynthesis rates in plants and increase apical meristem decapitation, which would increase the time required for the removed leaf area to recover (Brougham, 1956). However, using a severe (high) post-grazing height can also reduce intraspecific light competition by modifying the light environment in the canopy and promoting increased tissue and tiller renewal, thereby resulting in a younger population of tillers. Some studies have suggested that tiller age influences both morphogenetic and structural characteristics, thereby resulting in a progressive loss of vigor with advancing tiller age (Paiva et al., 2011).

Elephant grass (Pennisetum purpureum Schum.) has a high forage yield potential and is widely used in dairy farming. In this application, there is a potentially large influence of the tiller type that is produced or exploited on the balance between the physiological processes of photosynthesis and respiration, growth, tillering, and senescence, as large amounts of aerial tillers are produced in 
pastures. Despite its widespread use, knowledge regarding the forage accumulation process and the influence of various tiller classes and age ranges is scarce. Thus, the objective of this study was to assess the forage accumulation process in pastures of Elephant grass cv. Napier subjected to rotational grazing intensities and characterized by the pre-grazing condition of $95 \%$ light interception.

\section{Material and Methods}

This study was conducted in an area cultivated with Elephant grass cv. Napier in Viçosa, MG, Brazil $\left(20^{\circ} 45^{\prime} \mathrm{S}\right.$, $42^{\circ} 51^{\prime} \mathrm{W}, 651 \mathrm{~m}$ above the sea level). According to the Köppen classification, the climate is a subtropical Cwa type with discrete dry (colder months) and rainy (summer) seasons. Climate information was obtained from the meteorological station located at approximately $1,000 \mathrm{~m}$ from the experimental area (Figure 1). The monthly water balance was calculated using a water storage capacity of $50 \mathrm{~mm}$ (Thornthwaite \& Mather, 1955) (Figure 2).

The soil was classified as Inceptic Hapludults, with a clay-loam texture (EMBRAPA, 2006). Based on a chemical analysis of the 0-20 cm layer performed in December 2007, the soil exhibited the following characteristics: $\mathrm{pH}$ in $\mathrm{H}_{2} \mathrm{O}=5.3 ; \mathrm{P}($ Mehlich-1 $)=1.7 \mathrm{mg} / \mathrm{dm}^{3}$ and $\mathrm{K}=34 \mathrm{mg} / \mathrm{dm}^{3}$; $\mathrm{Ca}^{+2}=2.0 \mathrm{cmol}_{\mathrm{c}} / \mathrm{dm}^{3} ; \mathrm{Mg}^{+2}=0.9 \mathrm{cmol}_{\mathrm{c}} / \mathrm{dm}^{3} ; \mathrm{H}+\mathrm{Al}=4.79$ $\mathrm{cmol}_{\mathrm{c}} / \mathrm{dm}^{3}$; cation exchange capacity $(\mathrm{T})=7.8 \mathrm{cmol}_{\mathrm{c}} / \mathrm{dm}^{3}$; and $\mathrm{V}=38 \%$. Based on these results, $2 \mathrm{t} / \mathrm{ha}$ of dolomitic limestone were applied, and a fertilization was also performed using $80 \mathrm{~kg} /$ ha of $\mathrm{P}_{2} \mathrm{O}_{5}$ (simple superphosphate) and of $\mathrm{K}_{2} \mathrm{O}$ (potassium oxide), in a single dose.

Because of the early apical meristem lengthening in Elephant grass cv. Napier and elevated aerial tillering following the decapitation of apical meristems of basal tillers (which are originally formed at the onset of each growing season), two experiments were conducted to assess three post-grazing heights: severe $(30 \mathrm{~cm})$, representing a high level of forage use; intermediate $(50 \mathrm{~cm})$; and lenient $(70 \mathrm{~cm})$. In the first experiment, which was conducted

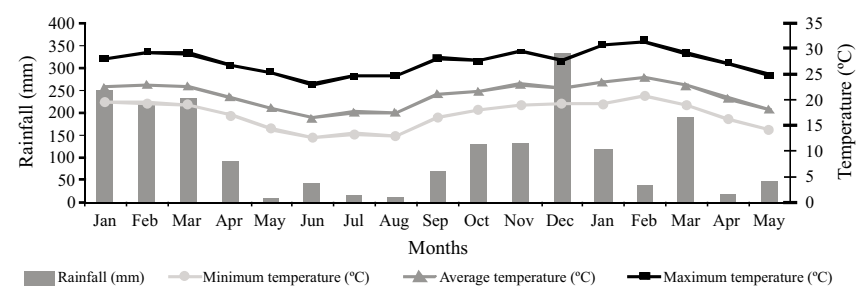

Figure 1 - Cumulative monthly rainfall and minimum, average and maximum air temperatures from January 2009 through May 2010. from February through May 2009, the timing of animal entry into the paddocks was based on the canopy light interception level and was independent of the initial decapitation height of the apical meristems of the basal tillers in the first grazing. The animals began grazing when light interception reached $95 \%$ and were removed from the paddocks when the post-grazing height targets of 30,50 or $70 \mathrm{~cm}$ were achieved. In the second experiment, which was conducted from December 2009 through May 2010, the first grazing was based on the height of the apical meristems of the existing basal tillers, and was independent of the canopy light interception level. Grazing was conducted when the meristems reached the specified postgrazing residual target heights of 30,50 , or $70 \mathrm{~cm}$. This strategy was aimed at removing the apical meristems of the basal tillers, thus ensuring that the intended post-grazing targets were achieved and stimulating rapid and vigorous regrowth from axillary buds (Hillesheim \& Corsi, 1990). In the subsequent grazing, the moment of animal entry into the paddocks was based on the light interception level, so that $95 \%$ of the incident light was intercepted. In both experiments, the treatments (post-grazing heights) were restricted to the experimental units (paddocks measuring $400 \mathrm{~m}^{2}$ ) according to a randomized complete block design with three replications.

Light interception within the pastures was monitored every seven days throughout the regrowth period. However, when the forage canopy intercepted over $90 \%$ of the incident light, the monitoring interval was reduced to two days until the target of $95 \%$ light interception was reached. Light interception was measured using a canopy analyzer apparatus (LAI 2000, LI-COR, Lincoln, Nebraska, USA) at four random points per experimental unit. At each point, a reading was taken above the canopy, and five readings were taken at the soil surface (below the canopy). In the second experiment, the height of the apical meristems of the basal tillers that resulted from the first grazing in the experiment was measured seven days after standardization by mowing to a height of $20 \mathrm{~cm}$ in November 2009. This

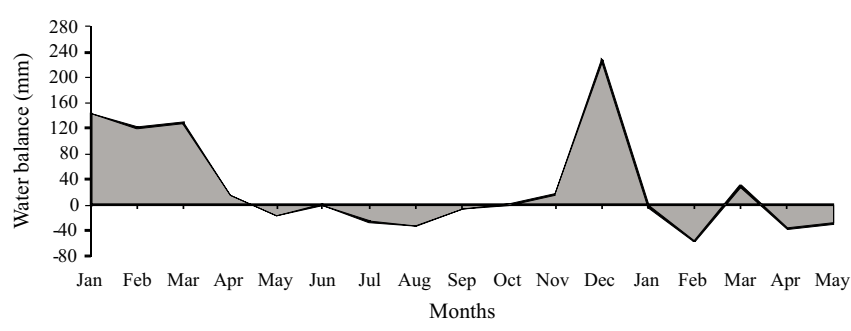

Figure 2 - Monthly water balance from January 2009 through May 2010. 
standardization cut was performed in experiment 1 , in January 2009 , at $20 \mathrm{~cm}$ above the soil. The measurement interval was reduced to two days when the apical meristem height approached the established target. Thus, 20 tillers were cut to the ground level and then opened lengthwise to view their apical meristems. Apical meristem height was measured as the distance between the tiller base and the apex of the apical meristem.

The canopy height was measured concomitantly to the evaluations of light interception at twenty points per experimental unit. It was estimated as the distance between the leaf horizon and the soil level.

During the experiments, the pastures received fertilization with an equivalent of $200 \mathrm{~kg} / \mathrm{ha}$ of nitrogen that was consistently applied in portions in the ammonium sulfate form after the animals had left the paddocks after each grazing cycle. In the first experiment, animals grazed 3,4 and 5 times on the pastures managed with post-grazing heights of 30,50 and $70 \mathrm{~cm}$, respectively. In the second experiment, animals grazed 4, 5 and 6 times on the pastures managed with respective post-grazing heights of 30, 50 and $70 \mathrm{~cm}$. Because the grazing interval and the conditions for animal entry into the pastures were not fixed, the amount of fertilizer that was applied to each paddock at each grazing cycle varied. Thus, $200 \mathrm{~kg} / \mathrm{ha}$ of nitrogen was divided by the period of grass growth (January-March) to obtain the daily amount to be applied to each paddock. The amount of fertilizer that was effectively applied was calculated by multiplying the daily amount by the previous rest period that occurred in each experimental unit. Hence, at the end of each experiment, every pasture had received the same amount of nitrogen $(200 \mathrm{~kg} / \mathrm{ha})$. Grazing was performed with crossbred steers weighing approximately $270 \mathrm{~kg}$, but no measurements of animal performance were made. The plots were sized so that the grazing period would last four to six hours. The animals were held in reserve pastures after exiting the paddocks and only returned to the experimental sites when the paddocks again reached pre-grazing conditions.

Dry matter accumulation dynamics were assessed for 12 tillers per experimental unit. These tillers were randomly marked (aerial and basal) at the onset of each regrowth period at points that were representative of the average canopy condition prior to grazing (based on a visual assessment of forage height and mass) and were assessed twice a week by measuring the length of the leaf blades and stems (stem + leaf sheaths). During the assessment period, any aerial tillers that emerged from the marked tillers were incorporated into the monitored group and assessed similarly. These assessments allowed us to estimate the rates of leaf and stem elongation and of leaf senescence (cm/tiller.day) (Lemaire \& Chapman, 1996). On the last day of each assessment period, each marked tiller was cut to the ground level (for the basal tillers) or to the insertion point (for the aerial tillers), packed in a plastic bag and immediately transported to a cold chamber to minimize moisture loss due to respiration and evaporation. After measuring the stems and leaves in the same manner as in the field, the leaf blades from each tiller and their respective stems were dried in a forced air oven at $65{ }^{\circ} \mathrm{C}$ for 72 hours. After drying, the material was weighed and the mass of each component was divided by its respective length, generating a mass-length conversion factor that was used to transform all of the field readings from $\mathrm{cm} /$ tiller. day to $\mathrm{mg} /$ tiller.day. A final transformation to $\mathrm{kg} / \mathrm{ha}$.day for the forage dry mass (DM) was performed by multiplying these values by the tiller density in each experimental unit and performing the necessary unit adjustments. The tiller density was calculated by counting the living tillers within four existing metal frames measuring $0.25 \mathrm{~m}^{2}(0.25 \times 1.00 \mathrm{~m})$ that were positioned at points that were representative of the average canopy condition prior to grazing (based on a visual assessment of forage height and mass). Thus, linear values for the rates of leaf and stem elongation and leaf senescence were transformed into rates of leaf and stem growth and leaf senescence ( $\mathrm{kg} /$ ha.day of DM), respectively, of the basal and aerial tillers. The sum of the leaf and stem growth was used as the total growth rate, and the forage accumulation rate was calculated as the difference between the rates of total growth and leaf senescence.

The data were organized by month and subjected to an analysis of variance using the MIXED procedure from the SAS statistical package (Statistical Analysis System, version 8.2) for Windows. The data set was tested to ensure that the basic assumptions for an analysis of variance were met. The Akaike Information Criterion was used to select the variance and covariance matrix (Wolfinger, 1993). Thus, it was possible to detect the effects of the main causes of variation (post-grazing height and month) and their interaction. The effects of post-grazing height and month and their interaction were considered fixed, and the effects of blocks and their interactions were considered random (Littel et al., 2000). The means were compared using Student's $t$-test at a 5\% significance level.

\section{Results}

The leaf growth rate in experiment one was influenced by the interaction between post-grazing height and month for both the basal $(\mathrm{P}=0.0246)$ and aerial tillers $(\mathrm{P}=0.0302)$. 
For the basal tillers, the leaf growth rate was generally lower in the pastures that were managed at a post-grazing height of $30 \mathrm{~cm}$ compared with those that were managed at 50 or $70 \mathrm{~cm}$ in February and March of 2009. These differences disappeared in April and May. For the aerial tillers, the difference between a post-grazing height of $30 \mathrm{~cm}$ and heights of 50 or $70 \mathrm{~cm}$ was maintained from February through May (Table 1). With the exception of the aerial tillers in the pastures that were managed at a postgrazing height of $30 \mathrm{~cm}$, the leaf growth rate decreased in the pastures throughout the year, and this result was independent of the tiller category.

The rate of stem growth in experiment one was influenced by the interaction between post-grazing height and month for both the basal $(\mathrm{P}=0.0002)$ and aerial tillers $(P=0.0051)$. In general, the stem growth rate for the basal tillers was lower in the pastures that were managed at a post-grazing height of $30 \mathrm{~cm}$ compared with the pastures that were managed at a height of 50 or $70 \mathrm{~cm}$ in February and March of 2009. These differences disappeared in April and May. For the aerial tillers, higher growth rates were observed from February through May in the pastures that were managed at a height of 50 or $70 \mathrm{~cm}$, compared with the pastures that were managed at $30 \mathrm{~cm}$ (Table 2). With the exception of the pastures that were managed at a postgrazing height of $30 \mathrm{~cm}$, the stem growth rate decreased in the pastures throughout the year, and this result was independent of the tiller category.

The leaf senescence rate in experiment one for the basal tillers was influenced only by the month $(\mathrm{P}=0.0074)$, with higher rates in February and March (30.7 and $28.5 \mathrm{~kg}$ /ha.day of DM, respectively) and lower rates in April and May of 2009 (18.3 and $18.2 \mathrm{~kg} /$ ha.day of DM, respectively). The

Table 1 - Leaf growth rate (kg/ha.day of DM) in Elephant grass cv. Napier pastures subjected to three post-grazing heights in experiment one

\begin{tabular}{|c|c|c|c|c|}
\hline \multirow{2}{*}{ Month } & \multicolumn{3}{|c|}{ Post-grazing height $(\mathrm{cm})$} & \multirow{2}{*}{ SEM } \\
\hline & 30 & 50 & 70 & \\
\hline \multicolumn{5}{|c|}{ Basal tillers } \\
\hline February 2009 & $67.1 \mathrm{Ab}$ & 139.1Aa & $140.3 \mathrm{Aa}$ & 12.65 \\
\hline March 2009 & $42.7 \mathrm{Ab}$ & $81.2 \mathrm{Ba}$ & $69.4 \mathrm{Ba}$ & 6.49 \\
\hline April 2009 & 15.9Ba & $16.8 \mathrm{Ca}$ & $16.3 \mathrm{Ca}$ & 1.60 \\
\hline May 2009 & $11.2 \mathrm{Ba}$ & $10.8 \mathrm{Da}$ & 7.9Da & 2.00 \\
\hline \multicolumn{5}{|c|}{ Aerial tillers } \\
\hline February 2009 & $9.2 \mathrm{Ab}$ & 24.2Bab & $33.5 \mathrm{Aa}$ & 5.12 \\
\hline March 2009 & $7.5 \mathrm{Ab}$ & $35.3 \mathrm{Aa}$ & $42.5 \mathrm{Aa}$ & 6.63 \\
\hline April 2009 & $5.3 \mathrm{Ac}$ & $14.5 \mathrm{Bb}$ & $18.1 \mathrm{Ba}$ & 0.89 \\
\hline May 2009 & $3.4 \mathrm{Ab}$ & $8.4 \mathrm{Ca}$ & $9.4 \mathrm{Ca}$ & 0.65 \\
\hline
\end{tabular}

For each tiller category, means followed by the same uppercase letter in the column and lowercase letter in the row do not differ significantly based on Student's t-test $(\mathrm{P}>0.05)$.

SEM - standard error of the mean. leaf senescence rate for the aerial tillers was affected by the interaction between post-grazing height and month $(\mathrm{P}<0.0001)$. Higher rates were recorded in the pastures managed at a post-grazing height of $70 \mathrm{~cm}$ than in the pastures managed at 30 or $50 \mathrm{~cm}$ in February and March. These differences disappeared in April and May (Table 3). The leaf senescence rate increased in the pastures managed at a height of $50 \mathrm{~cm}$ throughout the year and decreased in the pastures managed at $70 \mathrm{~cm}$; no change was observed in the pastures managed at $30 \mathrm{~cm}$.

The total growth rate in experiment one was influenced by the interaction between post-grazing height and month for both the basal $(\mathrm{P}<0.0001)$ and aerial tillers $(\mathrm{P}=0.0287)$. The total growth rate for the basal tillers was higher in the pastures managed at a post-grazing height of 70 or 50 $\mathrm{cm}$ than in the pastures managed at a height of $30 \mathrm{~cm}$ in February 2009. In March, the highest rates were obtained in the pastures managed at a post-grazing height of $50 \mathrm{~cm}$, intermediate rates were found in the pastures managed at $70 \mathrm{~cm}$, and the lowest rates were observed in the pastures managed at $30 \mathrm{~cm}$. These differences disappeared in the fall (i.e., April and May) (Table 4). The highest rates occurred

Table 2 - Stem growth rate $(\mathrm{kg} / \mathrm{ha}$.day of DM) in Elephant grass cv. Napier pastures subjected to three post-grazing heights in experiment one

\begin{tabular}{lcccr}
\hline \multirow{4}{*}{ Month } & \multicolumn{3}{c}{ Post-grazing height $(\mathrm{cm})$} & \multirow{2}{*}{ SEM } \\
\cline { 2 - 3 } & \multicolumn{3}{c}{ Basal tillers } \\
\cline { 2 - 4 } February 2009 & $36.1 \mathrm{Ab}$ & $136.7 \mathrm{Aa}$ & $128.9 \mathrm{Aa}$ & 8.80 \\
March 2009 & $41.2 \mathrm{Ac}$ & $108.3 \mathrm{Ba}$ & $83.1 \mathrm{Bb}$ & 6.87 \\
April 2009 & $44.2 \mathrm{Aa}$ & $55.1 \mathrm{Ca}$ & $50.2 \mathrm{Ca}$ & 13.21 \\
May 2009 & $26.6 \mathrm{Aa}$ & $23.3 \mathrm{Da}$ & $31.6 \mathrm{Ca}$ & 8.09 \\
& & Aerial tillers & & \\
February 2009 & $3.7 \mathrm{Ab}$ & $13.2 \mathrm{Bab}$ & $17.0 \mathrm{BCa}$ & 3.07 \\
March 2009 & $4.7 \mathrm{Ab}$ & $29.3 \mathrm{Aa}$ & $29.3 \mathrm{Aa}$ & 6.28 \\
April 2009 & $5.3 \mathrm{Ab}$ & $14.0 \mathrm{Ba}$ & $17.9 \mathrm{Ba}$ & 2.16 \\
May 2009 & $3.0 \mathrm{Ab}$ & $8.7 \mathrm{Ca}$ & $8.2 \mathrm{Ca}$ & 0.99 \\
\hline
\end{tabular}

For each tiller category, means followed by the same uppercase letter in the column and lowercase letter in the row do not differ significantly based on Student's t-test $(\mathrm{P}>0.05)$.

SEM - standard error of the mean.

Table 3 - Leaf senescence rate of aerial tillers ( $\mathrm{kg} / \mathrm{ha}$.day of DM) in Elephant grass cv. Napier pastures subjected to three post-grazing heights in experiment one

\begin{tabular}{lccrc}
\hline \multirow{2}{*}{ Month } & \multicolumn{3}{c}{ Post-grazing height $(\mathrm{cm})$} & \multirow{2}{*}{ SEM } \\
\cline { 2 - 3 } & 30 & 50 & 70 & \\
\hline February 2009 & $1.2 \mathrm{Ab}$ & $1.6 \mathrm{Bb}$ & $11.8 \mathrm{Aa}$ & 1.00 \\
March 2009 & $2.2 \mathrm{Ab}$ & $2.4 \mathrm{ABb}$ & $8.1 \mathrm{Ba}$ & 0.90 \\
April 2009 & $3.3 \mathrm{Aa}$ & $2.4 \mathrm{ABa}$ & $2.6 \mathrm{Ca}$ & 0.30 \\
May 2009 & $1.2 \mathrm{Aa}$ & $3.6 \mathrm{Aa}$ & $4.3 \mathrm{Ca}$ & 0.70 \\
\hline
\end{tabular}

Means followed by the same uppercase letter in the column and lowercase letter in the row do not differ significantly based on Student's t-test $(\mathrm{P}>0.05)$.

SEM - standard error of the mean. 
in February and March, and the lowest rates occurred in April and May; these results were independent of postgrazing height. In general, higher total growth rates for the aerial tillers were observed in the pastures managed at a post-grazing height of 70 or $50 \mathrm{~cm}$, compared with those managed at $30 \mathrm{~cm}$. With the exception of the pastures that were managed at a post-grazing height of $30 \mathrm{~cm}$, higher total growth rates were recorded in March, with a decrease observed in April, reaching its minimum in May.

The forage accumulation rate in experiment one was influenced by the interaction between post-grazing height and month for both the basal $(\mathrm{P}=0.0378)$ and aerial tillers $(\mathrm{P}=0.0328)$. For the basal tillers, the pastures managed at a post-grazing height of 70 or $50 \mathrm{~cm}$ exhibited higher rates in February and March 2009 than those managed at $30 \mathrm{~cm}$. These differences disappeared in the fall (i.e., April and

Table 4 - Total growth rate $(\mathrm{kg} /$ ha.day of DM) in Elephant grass cv. Napier pastures subjected to three post-grazing heights in experiment one

\begin{tabular}{lcccr}
\hline \multirow{4}{*}{ Month } & \multicolumn{3}{c}{ Post-grazing height $(\mathrm{cm})$} & \multirow{2}{*}{ SEM } \\
\cline { 2 - 3 } & \multicolumn{3}{c}{ Basal tillers } \\
\cline { 2 - 4 } February 2009 & $103.2 \mathrm{Ab}$ & $275.8 \mathrm{Aa}$ & $269.1 \mathrm{Aa}$ & 12.16 \\
March 2009 & $83.9 \mathrm{Ac}$ & $189.5 \mathrm{Ba}$ & $152.6 \mathrm{Bb}$ & 10.44 \\
April 2009 & $60.1 \mathrm{Ba}$ & $71.9 \mathrm{Ca}$ & $66.5 \mathrm{Ca}$ & 15.31 \\
May 2009 & $37.8 \mathrm{Ca}$ & $34.1 \mathrm{Ca}$ & $39.5 \mathrm{Ca}$ & 9.06 \\
& & Aerial tillers & \\
February 2009 & $12.9 \mathrm{Ab}$ & $37.4 \mathrm{ABab}$ & $50.5 \mathrm{Ba}$ & 5.50 \\
March 2009 & $12.2 \mathrm{Ab}$ & $64.5 \mathrm{Aa}$ & $71.8 \mathrm{Aa}$ & 11.43 \\
April 2009 & $10.7 \mathrm{Ab}$ & $28.6 \mathrm{Ba}$ & $36.0 \mathrm{Ba}$ & 3.34 \\
May 2009 & $6.3 \mathrm{Ab}$ & $17.1 \mathrm{Ca}$ & $17.6 \mathrm{Ca}$ & 1.69 \\
\hline
\end{tabular}

For each tiller category, means followed by the same uppercase letter in the column and lowercase letter in the row do not differ significantly based on Student's t-test $(\mathrm{P}>0.05)$.

SEM - standard error of the mean.

Table 5 - Forage accumulation rate (kg/ha.day of DM) in Elephant grass cv. Napier pastures subjected to three post-grazing heights in experiment one

\begin{tabular}{|c|c|c|c|c|}
\hline \multirow{2}{*}{ Month } & \multicolumn{3}{|c|}{ Post-grazing height $(\mathrm{cm})$} & \multirow{2}{*}{ SEM } \\
\hline & 30 & 50 & 70 & \\
\hline \multicolumn{5}{|c|}{ Basal tillers } \\
\hline February 2009 & $82.1 \mathrm{Ab}$ & 248.7Aa & $225.3 \mathrm{Aa}$ & 17.36 \\
\hline March 2009 & $62.8 \mathrm{ABb}$ & $160.5 \mathrm{Ba}$ & $117.2 \mathrm{Ba}$ & 13.69 \\
\hline April 2009 & $39.2 \mathrm{Aba}$ & $55.5 \mathrm{Ca}$ & $48.8 \mathrm{Ca}$ & 10.10 \\
\hline May 2009 & $21.5 \mathrm{Ba}$ & $13.5 \mathrm{Da}$ & $21.3 \mathrm{Da}$ & 3.71 \\
\hline \multicolumn{5}{|c|}{ Aerial tillers } \\
\hline February 2009 & $11.7 \mathrm{Ab}$ & $35.8 \mathrm{BCa}$ & $38.7 \mathrm{Ba}$ & 3.70 \\
\hline March 2009 & $10.0 \mathrm{Ab}$ & $62.1 \mathrm{Aa}$ & 63.7Aa & 11.24 \\
\hline April 2009 & $7.4 \mathrm{Ab}$ & $26.2 \mathrm{ABa}$ & $33.4 \mathrm{Ba}$ & 3.22 \\
\hline May 2009 & $4.2 \mathrm{Ab}$ & $13.5 \mathrm{Ca}$ & $13.2 \mathrm{Ca}$ & 1.82 \\
\hline
\end{tabular}

For each tiller category, means followed by the same uppercase letter in the column and lowercase letter in the row do not differ significantly based on Student's t-test $(\mathrm{P}>0.05)$.

SEM - standard error of the mean.
May) (Table 5). The forage accumulation rates decreased throughout the year. For the aerial tillers, there was no significant difference among the post-grazing heights in February 2009. From March through May, however, higher rates were observed in the pastures managed at a postgrazing height of 70 or $50 \mathrm{~cm}$ than the pastures managed at $30 \mathrm{~cm}$ (Table 5). With the exception of the pastures managed at a post-grazing height of $30 \mathrm{~cm}$, the forage accumulation rates reached their highest values in March, and this trend was followed by a decrease in April and May.

The leaf growth rate of the basal tillers in experiment two was influenced by the interaction between post-grazing height and month $(\mathrm{P}<0.0001)$. There was no difference in rates between the post-grazing heights at the onset of the experiment, in December 2009. From January through March 2010, there was a significant difference in rates between the heights of 30 and $50 \mathrm{~cm}$ : the highest rates were observed in the pastures managed at $70 \mathrm{~cm}$; intermediate rates were observed in the pastures managed at $50 \mathrm{~cm}$; and the lowest rates were obtained in the pastures managed at $30 \mathrm{~cm}$. These differences disappeared in the two final months of the experiment (April and May) (Table 6). In general, the growth rates were the highest during the summer months (December-March) and decreased during the fall (April and May), and this effect was independent of the post-grazing height. For the aerial tillers, the growth rate was affected only by the post-grazing height $(\mathrm{P}=0.0245)$, with the highest rates observed in the pastures managed at a post-grazing height of $70 \mathrm{~cm}(19.7 \mathrm{~kg} /$ ha.day of DM); intermediate rates observed in the pastures managed at $50 \mathrm{~cm}$ $(13.0 \mathrm{~kg} / \mathrm{ha}$.day of DM); and lowest rates verified in the pastures managed at $30 \mathrm{~cm}(6.1 \mathrm{~kg} / \mathrm{ha}$.day of DM).

The stem growth rate in experiment two was affected by the interaction between post-grazing height and month for both basal $(P=0.0364)$, and aerial tillers $(P=0.0365)$. For the basal tillers, from December 2009 through April 2010, the highest values were generally observed in the pastures

Table 6 - Leaf growth rate of basal tillers $(\mathrm{kg} /$ ha.day of DM) in Elephant grass cv. Napier pastures subjected to three post-grazing heights in experiment two

\begin{tabular}{llllr}
\hline \multirow{2}{*}{ Month } & \multicolumn{3}{c}{ Post-grazing height $(\mathrm{cm})$} & \multirow{2}{*}{ SEM } \\
\cline { 2 - 4 } & \multicolumn{1}{c}{30} & \multicolumn{1}{c}{50} & 70 & \\
\hline December 2009 & $40.0 \mathrm{Aa}$ & $56.5 \mathrm{Aa}$ & $50.6 \mathrm{Ba}$ & 7.04 \\
January 2010 & $27.2 \mathrm{ABb}$ & $56.1 \mathrm{Aab}$ & $79.7 \mathrm{Aa}$ & 10.41 \\
February 2010 & $23.9 \mathrm{ABb}$ & $42.6 \mathrm{ABb}$ & $84.1 \mathrm{Aa}$ & 8.57 \\
March 2010 & $25.3 \mathrm{ABb}$ & $36.6 \mathrm{ABab}$ & $52.8 \mathrm{Ba}$ & 9.39 \\
April 2010 & $22.4 \mathrm{Ba}$ & $28.5 \mathrm{BCa}$ & $21.5 \mathrm{Ca}$ & 6.76 \\
May 2010 & $21.9 \mathrm{Ba}$ & $17.5 \mathrm{Ca}$ & $17.2 \mathrm{Ca}$ & 3.07 \\
\hline
\end{tabular}

Means followed by the same uppercase letter in the column and lowercase letter in the row do not differ significantly based on Student's t-test $(\mathrm{P}>0.05)$.

SEM - standard error of the mean. 
managed at a post-grazing height of $70 \mathrm{~cm}$; intermediate rates were obtained in the pastures managed at $50 \mathrm{~cm}$ (except March 2010); and the lowest rates were obtained in the pastures managed at $30 \mathrm{~cm}$. In May, higher rates were obtained in the pastures managed at a post-grazing height of 70 or $50 \mathrm{~cm}$ than in the pastures maintained at a post-grazing height of $30 \mathrm{~cm}$ (Table 7). For the aerial tillers, at the onset of the experiment, in December 2009, a higher stem growth rate was observed in the pastures managed at a post-grazing height of 50 or $70 \mathrm{~cm}$ in relation to those managed at $30 \mathrm{~cm}$. In January and February 2010, a difference between the post-grazing heights was detected, with the highest rates in the pastures managed at a post-grazing height of $70 \mathrm{~cm}$, intermediate rates in the pastures managed at $50 \mathrm{~cm}$, and lowest values in the pastures managed at $30 \mathrm{~cm}$.

The leaf senescence rate in experiment two was influenced only by the month for both the basal $(\mathrm{P}<0.0001)$ and aerial tillers $(\mathrm{P}=0.0034)$. At the onset of the experiment, the mean leaf senescence rates of the basal and aerial tillers were 14.2 and $0.3 \mathrm{~kg} / \mathrm{ha}$.day of DM, respectively. These rates increased in January (to 17.6 and $5.0 \mathrm{~kg} / \mathrm{ha}$.day of DM, respectively) and February 2010 (to 18.4 and $6.0 \mathrm{~kg} /$ ha.day of DM, respectively), and then decreased in March (to 15.7 and $3.0 \mathrm{~kg} /$ ha.day DM, respectively), reaching even lower values in April (11.4 and $1.7 \mathrm{~kg} /$ ha.day of DM, respectively) and May 2010 (5.3 and $2.6 \mathrm{~kg} /$ ha.day of DM, respectively).

The total growth rate of the basal tillers in experiment two was affected by the interaction between post-grazing height and month $(\mathrm{P}=0.0072)$. At the onset of the experiment, the highest total growth rate was observed in

Table 7 - Stem growth rate ( $\mathrm{kg} /$ ha.day of DM) in Elephant grass cv. Napier pastures subjected to three post-grazing heights in experiment two

\begin{tabular}{|c|c|c|c|c|}
\hline \multirow{2}{*}{ Month } & \multicolumn{3}{|c|}{ Post-grazing height $(\mathrm{cm})$} & \multirow{2}{*}{ SEM } \\
\hline & 30 & 50 & 70 & \\
\hline \multicolumn{5}{|c|}{ Basal tillers } \\
\hline December 2009 & $20.5 \mathrm{Bb}$ & $34.5 \mathrm{Bab}$ & $37.6 \mathrm{Ca}$ & 5.32 \\
\hline January 2010 & $19.2 \mathrm{Bc}$ & $38.6 \mathrm{Bb}$ & 71.1Aa & 5.32 \\
\hline February 2010 & 9.9BCc & $33.0 \mathrm{Bb}$ & $61.0 \mathrm{ABa}$ & 5.32 \\
\hline March 2010 & $41.0 \mathrm{Ab}$ & $44.7 \mathrm{ABb}$ & $63.0 \mathrm{ABa}$ & 5.32 \\
\hline April 2010 & $28.2 \mathrm{Ac}$ & $56.3 \mathrm{Ab}$ & $72.5 \mathrm{Aa}$ & 5.32 \\
\hline May 2010 & $6.45 \mathrm{Cb}$ & $45.1 \mathrm{ABa}$ & $49.2 \mathrm{BCa}$ & 5.32 \\
\hline \multicolumn{5}{|c|}{ Aerial tillers } \\
\hline December 2009 & 4.7ABb & $12.4 \mathrm{Aa}$ & $9.8 \mathrm{Aab}$ & 2.10 \\
\hline January 2010 & $2.7 \mathrm{Cc}$ & $7.1 \mathrm{Bb}$ & $10.0 \mathrm{Aa}$ & 0.50 \\
\hline February 2010 & $2.8 \mathrm{BCc}$ & $6.1 \mathrm{Cb}$ & 9.8Aa & 0.50 \\
\hline March 2010 & $5.3 \mathrm{Ab}$ & $9.2 \mathrm{Aa}$ & $11.5 \mathrm{Aa}$ & 1.29 \\
\hline April 2010 & $6.0 \mathrm{Ab}$ & $9.6 \mathrm{Aa}$ & $9.3 \mathrm{Aa}$ & 1.29 \\
\hline May 2010 & $3.3 \mathrm{BCb}$ & 7.3BCa & $6.5 \mathrm{Ba}$ & 1.29 \\
\hline
\end{tabular}

the pastures managed at a post-grazing height of $50 \mathrm{~cm}$; intermediate rates were found in the pastures managed at $70 \mathrm{~cm}$; and the lowest rates were obtained in the pastures managed at $30 \mathrm{~cm}$. From January through March 2010, there was a difference between the post-grazing heights: the highest rates were observed in the pastures managed at a post-grazing height of $70 \mathrm{~cm}$; intermediate rates were found in the pastures managed at $50 \mathrm{~cm}$; and the lowest rates were obtained in the pastures managed at $30 \mathrm{~cm}$. In April and May, the pastures managed at a post-grazing height of 70 or $50 \mathrm{~cm}$ exhibited higher total growth rates than the pastures managed at $30 \mathrm{~cm}$ (Table 8). The total growth rate in the pastures managed at a post-grazing height of $30 \mathrm{~cm}$ decreased in January and February of 2010, increased in March, and then decreased again in May. In contrast, the total growth rate in the pastures managed at a height of $70 \mathrm{~cm}$ increased in February and then decreased throughout the rest of the year. In the pastures managed at a postgrazing height of $50 \mathrm{~cm}$, the rates were stable throughout the experimental period. The total growth rate of the aerial tillers was influenced by both post-grazing height $(\mathrm{P}=0.0181)$ and month $(\mathrm{P}<0.0001)$. Higher rates were observed in the pastures managed at a post-grazing height of $70(29.1 \mathrm{~kg} /$ ha.day of DM) or $50 \mathrm{~cm}(21.6 \mathrm{~kg} /$ ha.day of DM) than in the pastures managed at $30 \mathrm{~cm}(10.2 \mathrm{~kg} / \mathrm{ha}$.day of DM). The total growth rates in December 2009 and January 2010 were 22.1 and $19.1 \mathrm{~kg} / \mathrm{ha}$.day of DM, respectively; the rate decreased in February (to $17.1 \mathrm{~kg} /$ ha.day of DM), increased again in March (to $23.9 \mathrm{~kg} / \mathrm{ha}$.day of DM), and then decreased again in April (to $22.1 \mathrm{~kg} / \mathrm{ha}$.day of DM) and May (to $17.6 \mathrm{~kg} /$ ha.day of DM).

The forage accumulation rate of the basal tillers in experiment two was affected by the interaction between post-grazing height and month $(\mathrm{P}=0.0086)$. At the onset of the experiment, higher rates were observed in the pastures managed at a post-grazing height of 70 or $50 \mathrm{~cm}$ compared with the pastures managed at a height of $30 \mathrm{~cm}$. From

Table 8 - Total growth rate of basal tillers $(\mathrm{kg} / \mathrm{ha}$.day of DM) in Elephant grass cv. Napier pastures subjected to three post-grazing heights in experiment two

\begin{tabular}{llccr}
\hline \multirow{2}{*}{ Month } & \multicolumn{3}{c}{ Post-grazing height $(\mathrm{cm})$} & \multirow{2}{*}{ SEM } \\
\cline { 2 - 4 } & \multicolumn{1}{c}{30} & 50 & 70 & \\
\hline December 2009 & $60.5 \mathrm{Ab}$ & 90.9Aa & $88.3 \mathrm{CDab}$ & 10.3 \\
January 2010 & $46.4 \mathrm{Abc}$ & $94.7 \mathrm{Ab}$ & $164.6 \mathrm{Aa}$ & 9.8 \\
February 2010 & $33.9 \mathrm{BCc}$ & 75.6Ab & $145.1 \mathrm{Aba}$ & 12.3 \\
March 2010 & 66.3Ac & 81.3Ab & $128.7 \mathrm{Ba}$ & 9.9 \\
April 2010 & $50.6 \mathrm{ABb}$ & 84.8Aa & $94.0 \mathrm{Ca}$ & 9.3 \\
May 2010 & $28.4 \mathrm{Cb}$ & $71.6 \mathrm{Aa}$ & $66.4 \mathrm{Da}$ & 8.9 \\
\hline
\end{tabular}

Means followed by the same uppercase letter in the column and lowercase letter in the row do not differ significantly based on Student's t-test $(\mathrm{P}>0.05)$.

SEM - standard error of the mean. 
Table 9 - Forage accumulation rate of basal tillers $(\mathrm{kg} /$ ha.day of DM) in Elephant grass cv. Napier pastures subjected to three post-grazing heights in experiment two

\begin{tabular}{llccc}
\hline \multirow{2}{*}{ Month } & \multicolumn{3}{c}{ Post-grazing height $(\mathrm{cm})$} & \multirow{2}{*}{ SEM } \\
\cline { 2 - 4 } & \multicolumn{1}{c}{30} & 50 & 70 & \\
\hline December 2009 & $48.0 \mathrm{Ab}$ & $76.0 \mathrm{Aa}$ & $73.2 \mathrm{CDa}$ & 8.89 \\
January 2010 & $31.8 \mathrm{ABb}$ & $56.7 \mathrm{Ab}$ & $144.1 \mathrm{Aa}$ & 8.89 \\
February 2010 & $32.0 \mathrm{ABb}$ & $57.6 \mathrm{Ab}$ & $123.9 \mathrm{Aba}$ & 8.89 \\
March 2010 & $50.1 \mathrm{Ab}$ & $69.0 \mathrm{Ab}$ & $112.1 \mathrm{Ba}$ & 8.89 \\
April 2010 & $37.4 \mathrm{ABb}$ & $78.3 \mathrm{Aa}$ & $79.4 \mathrm{Ca}$ & 8.89 \\
May 2010 & $23.4 \mathrm{Bb}$ & $68.0 \mathrm{Aa}$ & $54.3 \mathrm{Da}$ & 8.89 \\
\hline
\end{tabular}

Means followed by the same uppercase letter in the column and lowercase letter in the row do not differ significantly based on Student's t-test $(\mathrm{P}>0.05)$. SEM - standard error of the mean.

January through March 2010, the pastures managed at a post-grazing height of $70 \mathrm{~cm}$ showed a higher rate than the pastures managed at 50 or $30 \mathrm{~cm}$. In the fall (i.e., April and May), higher rates were obtained in the pastures managed at a post-grazing height of 70 or $50 \mathrm{~cm}$ than in the pastures managed at $30 \mathrm{~cm}$ (Table 9). The forage accumulation rate of the aerial tillers was influenced by post-grazing height $(\mathrm{P}=0.0264)$ and month $(\mathrm{P}<0.0001)$. Higher rates were observed in the pastures managed at a post-grazing height of $70 \mathrm{~cm}(24.7 \mathrm{~kg} / \mathrm{ha}$.day of DM) or $50 \mathrm{~cm}(19.1 \mathrm{~kg} / \mathrm{ha}$.day of $\mathrm{DM}$ ) in relation to the pastures managed at $30 \mathrm{~cm}$ $(8.1 \mathrm{~kg} / \mathrm{ha}$.day of DM). At the onset of the experiment, the forage accumulation rate was high $(21.0 \mathrm{~kg} /$ ha.day of DM); it then decreased in January (to $14.2 \mathrm{~kg} /$ ha.day of DM) and February 2010 (11.4 kg/ha.day of DM), increased again in March (to $20.9 \mathrm{~kg} / \mathrm{ha}$.day of DM) and April (20.4 kg/ha.day of DM), and then decreased in May (to $15.0 \mathrm{~kg} / \mathrm{ha}$.day of DM).

\section{Discussion}

The canopy height under the pre-grazing condition varied from 83 to $97 \mathrm{~cm}$ in the summer, and from 71 to $85 \mathrm{~cm}$ in the fall in experiment 1 . In experiment 2 , it varied from 99 to $108 \mathrm{~cm}$ in the summer and from 92 to $95 \mathrm{~cm}$ in the fall. This variation may be associated with the short adaptation period of the pastures. According to Da Silva et al. (2008) the relation between $95 \%$ of light interception and the canopy height is only appropriate when the pastures are regularly used and also with the control of the grazing process. Thus, for the establishment of the target pre-grazing height of Elephant grass cv. Napier, more research should be carried out for longer periods. Despite the variation, which may be associated in parts with the shorter duration of the first experiment in comparison with the second one, these values are near those reported by Voltolini (2006) for Elephant grass cv. Cameroon. These authors revealed that the light interception of $95 \%$ of incident light by the canopy for that forage plant coincides with the average height of $100 \mathrm{~cm}$. It must also be emphasized that these height values are inferior to the 170 to $180 \mathrm{~cm}$ (Deresz et al., 2006) historically recommended for the management of Elephant grass under grazing.

Regardless of the strategy selected with respect to the onset of grazing in Elephant grass pastures (with the first grazing performed at the $95 \%$ light interception target - experiment one - or when the apical meristems were at the residue target-heights - experiment two) and the tiller category (basal or aerial), the pastures managed at a postgrazing height of $30 \mathrm{~cm}$ during the summer months showed lower rates of leaf growth (Tables 1 and 6) and stem growth (Tables 2 and 7), and consequently, lower rates of total growth (Tables 4 and 8 ) and forage accumulation (Tables 5). The most intense grazing (i.e., to a length of $30 \mathrm{~cm}$ ) removes higher quantities of forage. Under these conditions, initial regrowth is slow, despite an improved light environment due to increases in the quantity and quality of light within the canopy (Brougham, 1956); this slow growth rate is due to a smaller amount of leaves, which results in a limited photosynthetic capacity after grazing (Parsons \& Penning, 1988). Thus, carbon fixation and the production of organic compounds are reduced, which increases the time required to replenish the biomass (Parsons et al., 1983). Additionally, intensive grazing promotes increased tiller decapitation, which further reduces regrowth vigor because of the need to allocate photoassimilates for the differentiation and division of new cells to form new meristems and tillers (Taiz \& Zeiger, 2009).

The lower rates of leaf and stem growth, total growth and of forage accumulation observed in the pastures managed at a post-grazing height of $30 \mathrm{~cm}$ suggest that this post-grazing height was exceedingly low (Sousa, 2009) and was likely too severe for proper management of Elephant grass cv. Napier. These pastures also presented lower mass and forage accumulation, lower tiller density, lower tiller renewal, and lower quantity of weeds (Monteiro, 2011). Nevertheless, it is worth remarking that the Elephant grass is a plant that demands fertility of soil (Pereira et al., 2010). Throughout the experimental period, the acidity and the fertility of the soil were not assessed; it was only fertilized with nitrogen. Therefore, this reduction in the growth of the basal and aerial tillers is possibly due to the higher removal of forage and lower recycling of nutrients (Da Silva et al., 2008) associated with the low level of natural fertility of the soil in the experimental area $\left(\mathrm{P}=1.7 \mathrm{mg} / \mathrm{dm}^{3}\right.$ and $\left.\mathrm{V}=38 \%\right)$. Under high soil fertility conditions, this reduction in growth may not occur; therefore, this should be better evaluated 
so that practical recommendations of grazing management can be made.

Overall, the biomass accumulation rates did not differ between the post-grazing heights of 50 and $70 \mathrm{~cm}$, indicating either of these post-grazing heights would be appropriate for Elephant grass without compromising their remaining leaf area and organic reserves. However, the pastures managed at a post-grazing height of $50 \mathrm{~cm}$ exhibited relatively stable accumulation rates, particularly in experiment two, which suggests less seasonality in the yield that can be obtained in a single growing season. In addition, the pastures managed at a post-grazing height of $50 \mathrm{~cm}$ showed less stem accumulation than the pastures managed at $70 \mathrm{~cm}$, particularly in experiment two. These higher leaf and stem accumulation rates in pastures managed with a post-grazing height of $70 \mathrm{~cm}$ in relation to $50 \mathrm{~cm}$ were also recorded by Monteiro (2011), but they were estimated through cuts of forage in an area delimitated by an iron frame. Thus, the choice in the postgrazing height may be flexible, and the post-grazing height of $50 \mathrm{~cm}$ may be indicated if the aim is forage production in a more stable way, or $70 \mathrm{~cm}$ if one aims at higher leaf and stem production.

Leaf senescence rate was not affected by post-grazing height, and this result was independent of the management strategy that was used (i.e., experiment one or experiment two), which is likely due to the pre-grazing light interception target of $95 \%$. This condition is considered to be sufficient for regrowth interruption, for avoiding intense light competition, and for controlling leaf senescence and leaf death (Carnevalli et al., 2006).

In the fall, tissue growth was reduced, which was characterized by lower leaf (Tables 1 and 6) and stem (Tables 2) growth rates that consequently led to lower total growth (Tables 4 and 8) and forage accumulation (Tables 5) rates than in the summer. Also in the fall, the differences between post-grazing heights were diminished or disappeared. The forage accumulation process is strongly affected by variations in environmental conditions (Lemaire \& Chapman, 1996). The fall is characterized by lower temperatures, reduced precipitation (Figures 1 and 2), and less light (i.e., shorter days) than the summer, and these factors decreased forage production. The growth of forage plants in tropical climates is slowed at temperatures below $16{ }^{\circ} \mathrm{C}$ (Whitheman, 1980), which is due to a decreased rate of photosynthesis (Taiz \& Zeiger, 2009). In turn, a water deficit reduces the turgor pressure on the cell wall, which negatively affects leaf expansion and stimulates stomatal closing, thereby leading to reductions in both carbon dioxide absorption and the transfer of heat to the atmosphere, as well as a decreased absorption of nutrients, particularly nitrogen (Taiz \& Zeiger, 2009).

In addition, in the fall, Elephant grass cv. Napier is in its reproductive stage, which increases the stem growth rate, increases senescence relative to leaf growth, and reduces the rates of leaf growth, total growth and forage accumulation during this time of the year. In the reproductive stage, stem elongation increases, thereby making this component a potent sink for assimilates (Taiz \& Zeiger, 2009). Concomitantly, the apical meristem grows rapidly, thus reducing the distance that the new leaf flows inside the pseudostem and consequently reducing its length (Duru \& Ducrocq, 2000). This change in the patterns of photoassimilate translocation results in a higher production of stems than leaves. Once they reach maturity (i.e., the flowering stage), these tillers complete their life cycle and die. However, limited environmental conditions can prevent these tillers from being replaced with new ones, thereby leading to a net reduction in their population density (Sbrissa et al., 2010) and forage production.

Despite the fact that we conducted two experiments characterized by different management strategies for the first grazing, no statistical comparison was performed between these experiments. The decision to forego this analysis was based primarily on the existence of many factors that could have yielded confounding results, including different initiation times (February versus December 2009), different experimental periods (120 versus 180 days), and different climatic conditions between 2009 and 2010 (Figures 1 and 2). However, some inferences can be made with respect to the differences between these two experiments. Despite the differences in magnitude, the response patterns were similar and were independent of the year (i.e., higher rates were observed in the summer months, and these rates decreased with the onset of the fall). This response pattern likely occurred because distinct climatic conditions will affect the rate but not the process itself. Thus, in analyzing only the first two months of each experiment, it is evident that the strategy of decapitating the vast majority of the apical meristems only once (i.e., experiment two) resulted in a lower percentage of stem growth in relation to total growth $(38,39$ and $43 \%$ for the post-grazing heights of 30,50 , and $70 \mathrm{~cm}$, respectively) compared with the other management strategy (i.e., experiment one), which yielded 42,53 and $51 \%$ for the post-grazing heights of 30,50 and $70 \mathrm{~cm}$, respectively. This pattern appears to reflect the presence of more basal tillers with elongating stems in experiment one than in experiment two, in which there was a greater number of decapitated tillers. A higher proportion of stems can hinder maintenance at the recommended post- 
grazing height, as grazing animals may choose not to graze on these plants due to their lower nutritional value (Van Soest, 1994) and because stems are a physical barrier to grazing. Moreover, based on our analysis of leaf growth and senescence, it is clear that pastures that are managed using a strategy of decapitating the apical meristems throughout the grazing season (i.e., experiment one) exhibit higher senescence as compared with leaf growth. This management strategy thus resulted in negative leaf accumulation in May (fall), in which senescence was $26-30 \%$ higher than leaf growth. This result indicates that a strategy of decapitating most of the meristems of Elephant grass cv. Napier in the first grazing is appropriate. However, additional studies regarding this approach are needed, and these new studies should include longer experiment duration and cover a larger experimental area. In addition, the animals should be included as part of the response assessment procedure so that practical recommendations and more accurate management decisions can be reached.

In general, the contribution of aerial tillers in relation to basal tillers increased over the course of the experiments and with increasing post-grazing height. Thus, the respective participation of the aerial tillers at post-grazing heights of 30, 50 and $70 \mathrm{~cm}$ were as follows: $25.0,47.7$ and 54.3\% (in experiment one) and 26.3, 34 and 53.8\% (in experiment two) for leaf growth rate; 10.7, 27.2 and $26.3 \%$ (in experiment one) for stem growth rate; 13.6, 14.9 and $19.5 \%$ (in experiment one) for leaf senescence rate; $15.1,33.4$ and $35.1 \%$ (in experiment one) and 26, 20.5 and $28.9 \%$ (in experiment two) for total growth rate; and $16.3,50$ and $40.6 \%$ (in experiment one) and 24.3, 21.6 and $29.8 \%$ (in experiment two) for forage accumulation rate. An exception to this trend was as follows: for stem growth $(17.5,14.6$ and $11.4 \%$ at post-grazing heights of 30,50 and $70 \mathrm{~cm}$, respectively) and leaf senescence (37.5, 29.4 and $24.8 \%$ at post-grazing heights of 30,50 and $70 \mathrm{~cm}$, respectively) rates in experiment two, an elevated postgrazing height resulted in a decreased participation of aerial tillers compared with basal tillers. This higher contribution of aerial tillers throughout the experiments reflects an increase in their density in relation to basal tillers, which is possibly due to the fact that Elephant grass flowers in the fall. Furthermore, the contribution of aerial tillering was higher with higher post-grazing heights, which is a condition that leaves more substrate (e.g., more remaining stem after decapitation) for their recovery. Aerial tillers located in the upper canopy (as assessed visually) facilitate their removal by grazing animals, particularly in pastures that are managed at a lower post-grazing height.

\section{Conclusions}

The elevation in the residual post-grazing height, especially in the summer, elevates the regrowth vigor in the pasture of Elephant grass cv. Napier. The post-grazing height of $30 \mathrm{~cm}$ reduces the growth of the Elephant grass cv. Napier.

\section{References}

BIRCHAM, J.S.; HODGSON, J. The influence of sward condition on rates of herbage growth and senescence in mixed swards under continuous stocking management. Grass and Forage Science, v.38, p.323-331, 1983.

BROUGHAM, R.W. Effects of intensity of defoliation on regrowth of pasture. Australian Journal of Agricultural Research, v.7, p.377-387, 1956.

CARNEVALLI, R.A.; Da SILVA, S.C.; BUENO, A.A.O. et al. Herbage production and grazing losses in Panicum maximum cv. Mombaça under four grazing managements. Tropical Grasslands, v.40, p.165-176, 2006.

DA SILVA, S.C.; NASCIMENTO JÚNIOR, D.; EUCLIDES, V.B.P Pastagens: Conceitos básicos, produção e manejo. Viçosa, MG: Suprema, 2008. 115p

Da SILVA, S.C.; BUENO, A.A.O.; CARNEVALLI, R.A. et al. Sward structural characteristics and herbage accumulation of Panicum maximum cv. Mombaça subjected to rotational stocking managements. Scientia Agricola, v.66, n.1, p.8-19, 2009

DERESZ, F.; CÓSER, A.C.; MARTINS, C.E. Formação e utilização de pastagens de capim-elefante. 2.ed. Juiz de Fora: Embrapa Gado de Leite, 2006. (Instrução técnica).

DURU, M.; DUCROCQ, H. Growth and senescence of the successive grass leaves o a tiller ontogenic development and effect of temperature. Annals of Botany, v.85, p.635-643, 2000.

EMPRESA BRASILEIRA DE PESQUISA AGROPECUÁRIA EMBRAPA. Serviço Nacional de Levantamento e Conservação de Solos. Sistema brasileiro de classificação de solos. 2.ed. Rio de Janeiro: Embrapa Solos, 2006. 306p.

HILLESHEIM, A.; CORSI, M. Capim-elefante sob pastejo. Fatores que afetam o consumo. Pesquisa Agropecuária Brasileira, v.25, n.3, p.409-419, 1990.

LEMAIRE, G.; CHAPMAN, D. Tissue flows in grazed plant communities. In: HODGSON, J.; ILLIUS, A.W. (Eds.). The ecology and management of grazing systems. Wallingford: $\mathrm{CAB}$ International, 1996. p.3-36.

LITTEL, R.C.; PENDERGAST, J.; NATARAJAN, R. Modelling covariance structure in the analysis of repeated measures data. Statistics in Medicine, v.19, p.1793-1819, 2000.

MONTEIRO, H.C.F. Estrutura do dossel, acúmulo de forragem e dinâmica do perfilhamento em pastos de capim-elefante cv. Napier submetido a estratégias de pastejo rotativo. 2011. 133f. Tese (Doutorado em Zootecnia) - Universidade Federal de Viçosa, Viçosa, MG.

PAIVA, A.J.; Da SILVA, S.C.; PEREIRA, L.E.T. et al. Morphogenesis on age categories of tillers in Marandu palisadegrass. Scientia Agricola, v.68, n.6, p.626-631, 2011.

PARSONS, A.J.; LEAFE, E.L.; COLLETT, B. et al. The physiology of grass production under grazing. II. Photosynthesis, crop growth and animal intake of continuously grazed sward. Journal of Applied Ecology, v.20, p.127-139, 1983

PARSONS, A.J.; PENNING, P.D. The effect of the duration of regrowth on photosynthesis, leaf death and the average rate of growth in a rotationally grazed sward. Grass and Forage Science, v.43, n.1, p.15-27, 1988. 
PEREIRA, A.V.; AUAD, A.M.; LÉDO, F.J.S. et al. Pennisetum purpureum. In: FONSECA, D.M.; MARTUSCELLO, J.A. (Eds.). Plantas forrageiras. Viçosa, MG: UFV, 2010. p.197-219.

SBRISSIA, A.F.; Da SILVA, S.C.; SARMENTO, D.O.L. et al. Tillering dynamics in palisadegrass swards continuously stocked by cattle. Plant Ecology, v.206, p.349-359, 2010.

SOUSA, B.M.L. Morfogênese e características estruturais dos capins Andropógon e Xaraés submetidos a três alturas de corte. 2009. 108f. Dissertação (Mestrado em Zootecnia) - Universidade Federal de Viçosa, Viçosa, MG.

TAIZ, L.; ZEIGER, E. Fisiologia vegetal. 4.ed. Tradução SANTARÉM, E.R. et al. Porto Alegre: Artmed, 2009. 848p.

THORNTHWAITE, C.W.; MATHER, R.J. The water balance. New Jersey: Laboratory of Climatology, v.8, 1955. 104p.
VAN SOEST, P.J. Nutritional ecology of the ruminant. 2.ed. New York: Cornell University Press, 1994. 476p.

VOLTOLINI, T.V. Adequação protéica em rações com pastagens ou com cana-de-açúcar e efeito de diferentes intervalos entre desfolhas da pastagem de capim Elefante sobre o desempenho lactacional de vacas leiteiras. 2006. 167f. Tese (Doutorado em Agronomia) - Escola Superior de Agricultura "Luiz de Queiroz"/ Universidade de São Paulo, Piracicaba.

WHITHEMAN, P.C. Tropical pasture Science. New York: Oxford University Press, 1980. 392p.

WOLFINGER, R.D. Covariance structure selection in general mixed models. Communications in Statistics Simulation and Computation, v.22, n.4, p.1079-1106, 1993. 